\title{
Terrace Gardening
}

\section{Praneetha Gupta Komuravelli*}

Agronomist at Simply Fresh Private Limited, Hyderabad, Telangana, India

*Corresponding Author: Praneetha Gupta Komuravelli, Agronomist at Simply

Fresh Private Limited, Hyderabad, Telangana, India.
Received: March 01, 2021

Published: March 29, 2021

(C) All rights are reserved by Praneetha Gupta Komuravelli.



Figure

What is terrace gardening?

- Growing of fruits, flowers and vegetables in the terraces or balconies is known as terrace gardening.

Benefits of terrace gardening?

- Fresh supply of pampered veggies and fruits directly from your soil to soup.

- It helps in keeping your surroundings cool and refreshed.

- Lessens the $\mathrm{co}_{2}$ levels in your area.

- Improves the quality of air you breathe.

- It keeps you detached from all the stresses and havocs in the world.

- Gardening is always a great exercise, the more the efforts you put in, the more fit you stay.
Veggies that you can fit in your garden:

- $\quad$ All leafy greens-spinach, Amaranthus, Coriander, fenugreek, kale, basil, mint etc

- Vine crops-tomatoes, cucumbers, fruity peppers, gourds etc.

- $\quad$ Others such as carrot, chives, spring onion, radish etc

Tips for a successful terrace gardening:

- $\quad$ Proper drainage.

- Make use of old containers, boxes, bottles etc for cost effective garden.

- Avoid excess watering in the rainy season, water from the rains are sufficient.

- Do not keep the plants too close, they will compete for nutrients, sunlight and water.

- Use homemade compost for better results.

- $\quad$ Start with the plants which are low maintenance, easy to grow.

- Trim the flowering plants regularly with a rust-free or stainless-steel scissors to ensure bushy growth with numerous flowers.

- $\quad$ Pinching the drooped flower stalk, should be done regularly to encourage more flowering and healthier plant growth.

- A healthy garden must have a combination of different types of plants so that they attract essential pollinators.

- $\quad$ Strengthen your kinship with your plants so that you can spend a quality time in understanding the lifecycle of the plants. 
- It is sensible to grow aromatic plants if one is planning to have a vegetable garden. Aromatic plants (E.g. Curry leaves, mint, marigolds, Lemongrass, etc) have a strong aroma that helps in repelling the pests.

- $\quad$ Practice crop rotation, which means changing the crop of a single pot for every new time so that pest problem will be less.

- $\quad$ Finally, patience is the utmost important factor for any successful garden.

\section{Assets from publication with us}

- Prompt Acknowledgement after receiving the article

- Thorough Double blinded peer review

- Rapid Publication

- Issue of Publication Certificate

- High visibility of your Published work

Website: www.actascientific.com/

Submit Article: www.actascientific.com/submission.php

Email us: editor@actascientific.com

Contact us: +919182824667 